\title{
DIETARY LIPIDS REQUIREMENT FOR NILE TILAPIA (Oreochromis niloticus) LARVAE
}

\author{
A.E. Eid ${ }^{1}$, Ragaa A. Ahmed ${ }^{2}$, E.S. Baghdady ${ }^{1}$, Amal Elfeky ${ }^{1}$ and Asmaa S. Abd El_Naby ${ }^{3}$ \\ ${ }^{1}$ Department of Animal Production Faculty of agriculture, Suez, Canal-university. \\ ${ }^{2}$ Department of Aquaculture Faculty of Fish \& Fisheries Technology Aswan University. \\ 3. Department of Nutition.Central Laboratiry For Aquculture Research.. Abbassa Abohamad. Sharkia
}

(Received 2/7/2019, accepted 27/8/2019)

\section{SUMMARY}

\begin{abstract}
study was undertaken to determine the effect of the dietary lipid levels on growth performance, feed utilization and body composition of Nile tilapia larvae. Four isonitrogenous diets $(40 \%$ crude protein) and dietary lipid levels (4, 6, 8 and 10\% DM) were fed to satiation Nile tilapia larvae for 9 weeks. The best survival, weight gain, specific growth rate (SGR), protein efficiency ratio (PER), feed conversion ratio (FCR) and feed efficiency were observed for larvae fed $8 \%$ lipid level. While the poorest survival, specific growth rate (SGR), protein efficiency ratio (PER), lowest weight gain, specific growth rate (SGR), feed efficiency and highest feed conversion ratio (FCR), were observed with larvae fed $4 \%$ lipid level. The lipid content of fish were positively correlated with dietary lipid level. The body protein content increased with increasing the protein levels in the diet. It could be concluded that the requirement of lipid for Nile tilapia fry was $8 \%$ lipid under the present experimental condition.
\end{abstract}

Keywords: Lipid, requirement, feed utilization, Nile tilapia, growth performance and body composition.

\section{INTRODUCTION}

Tilapia is one of the most widely cultured fish in the world. Currently, farmed tilapia represents more than $75 \%$ of world tilapia production (FAO, 2009). Nile tilapia, (Oreochromis niloticus), belongs to the second most-produced group of freshwater fish worldwide, the tilapias and other cichlids (FAO, 2012, 2014).

Lipids are considered as one of the most important dietary components, which play a vital role in providing a source of energy and essential fatty acids. Lipids act as carriers of nutrients such as the fatsoluble vitamins A, D, E and $\mathrm{K}$ for fish, especially for carnivorous, cold-water fish and marine fish (Peng et al., 2015; Watanabe, 1982). Appropriate lipid content in the diet is important for growth performance of fish; furthermore, it is also vital for the formulation of diets and final product quality (Rahimnejad et al., 2015). However, excessive or deficient lipid in diets leads to decreased feed consumption, reduced growth and reduced health (Bonvini et al., 2015; Liao et al., 2016).

Dietary lipid was also reported to bring protein sparing effect, replacing protein, which may otherwise be used to provide energy (Watanabe ,1982; Beamish and Medland ,1986) to reduce organic matter and nitrogen losses (Lee and Putnam ,1973). In salmon aquaculture today, high fat diet has normally been used. But in many fish species, the increase of dietary lipid levels should be evaluated carefully because it may lead to increased fat deposition in fish. Some authors have observed no protein sparing effect of lipid in some fish species (Regost et al., 2001). A few studies have been performed to study nutritional requirements of lipid on growth performance and health of fish (Ahmadi et al., 2011).

The objective of the present study was to investigate the effect of dietary lipid levels on the growth performance, and body composition of Nile tilapia fry. 


\section{MATERIALS AND METHODS}

\section{Experimental fish:}

The present study was carried out at Fish Research Center, Faculty of Agriculture, Suez Canal University Ismailia Governorate. One thousand and two hundreds Nile tilapia (O. niloticus) fry with average initial weight of $0.4 \mathrm{~g}$ were used. Fish were homogenous in body weights and apparently healthy. Fish were acclimated to laboratory conditions for 2 weeks before the experiment started.

Fish were stocked in 12 Aquaria $(80 \mathrm{~cm}$ x $30 \mathrm{~cm}$ x $40 \mathrm{~cm}$ ) randomly divided into four equal experimental groups (100 fish each aquarium, three replicate/treatment) and aquaria were supplied with air blowers. The photoperiod was set on a 12-12 hour light-dark cycle using fluorescent tubes. Fish from each tank were collectively weighted every 10 days.

\section{Experimental diets:}

Four experimental diets were formulated from practical ingredients (Table 1). The experimental diets were formulated to contain almost $40 \%$ crude protein, and were prepared by individually weighing of each component. The minerals, vitamins and additives with corn were mixed with other ingredient. This mixture was added to the components together with oil. The produced diets were dried at room temperature then kept frozen until experimental start. These diets formulated to containing four levels of lipids (4, 6, 8 and 10\%). The composition and proximate analysis of the experimental diets are presented in (Table 1). The fish were fed handly to satiation, 10 times/day for Nile tilapia fry throughout the experimental period (63 days or 9 weeks).

\section{Chemiacal analysis of the experimental diets and fish:}

The tested diets and whole-fish body from each treatment at the beginning and at the end of experiment were analyzed according to the standard methods of AOAC (2004) for moisture, protein, fat, ash and the nitrogen free-extract (NFE \%) was calculated by the difference as shown in Table (1).

\section{Water Quality Parameters:}

Water temperature was maintained at $25^{\circ} \mathrm{C}$ by a 250 watt immersion heater with thermostat. Water temperature were recorded daily by Mercury thermometer, and dissolved oxygen by metteler Toledo, model 128.s/No1242. Where the average range of dissolved oxygen was above $5.47 \mathrm{mg} / \mathrm{l}$. Other water quality parameters including $\mathrm{pH}$ was measured every two days by $\mathrm{pH}$ meter (Extech $\mathrm{pH} /$ temp pen model $\mathrm{pH} 60$ ) where the average range of $\mathrm{pH}$ was in $7.7 \pm 0.7$ throughout the experimental period.

\section{Growth performance:}

At the end of experiment, fish were weighed and weight gain (WG), specific growth rate (SGR), feed efficiency ratio (FER), protein efficiency ratio (PER), were calculated using formulas in footnotes in Table (2).

\section{Statistical analysis:}

All of the data were analyzed by one-way analysis of variance (ANOVA) using the general linear models procedure of statistical analysis system (SAS, 1999) version 8.02. Duncan's multiple range test (Duncan, 1955) was used to resolve differences among treatment means at 5\% significant level.

\section{RESULTS AND DISCUSSION}

The growth performance of Nile tilapia fry (Oreochromis niloticus), which fed different lipid levels are shown in Table (2). Average body weight (g) of Nile tilapia larvae (Oreochromis niloticus), at the start were not differ, indicating that groups were homogenous. At the end of the experimental period (63 days) the group of fish fed $8 \%$ crude lipid, had significantly $(\mathrm{P}<0.05)$ the highest body weight gain. The lowest body weight gain $(3.70 \mathrm{~g})$ was achieved by group of fish fed lipid level $(4 \%)$.

Growth performance and feed utilization were significantly $(\mathrm{P}<0.05)$ affected by the dietary lipid level (Table 2). These results are in agreement with (Jauncey ,2000) who suggested that to maximize protein utilization, dietary fat concentration should be between 8 and $12 \%$ for tilapia up to $25 \mathrm{~g}$, and 6 to $8 \%$ for larger fish. Similar results were obtained by ( Sayed ,2017) who reveals that $8 \%$ lipid in diet of milkfish 
juveniles was optimal for the better growth and survival. In the present study, BWG, SGR, PER and FER increased with increasing lipid levels in the diets up to $8 \%$ crude lipid. The same trend was found by (Bromley, 1980 and Watanabe, 1982). Some other authors had reported that high dietary lipid levels might reduce fish growth (Garling and Wilson, 1977; Ellis and Reigh, 1991).

Table (1): Ingredients and Chemical composition of the experimental diets fed to Oreochromis niloticus larvae.

\begin{tabular}{|c|c|c|c|c|}
\hline \multirow{2}{*}{ Ingredient } & \multicolumn{4}{|c|}{ Lipid \% } \\
\hline & 4 & 6 & 8 & 10 \\
\hline Fish meal & 43 & 43 & 43 & 43 \\
\hline Soybean meal & 22 & 22 & 22 & 22 \\
\hline Yellow cornmeal & 30 & 28 & 30 & 32 \\
\hline Fish oil & - & 3 & 2 & 1 \\
\hline Corn oil & 3 & 2 & 1 & - \\
\hline Vitamin premix ${ }^{1}$ & 1 & 1 & 1 & 1 \\
\hline Mineral premix ${ }^{2}$ & 1 & 1 & 1 & 1 \\
\hline \multicolumn{5}{|c|}{ Proximate chemical analysis of experimental diets ( $\%$ on dry matter basis). } \\
\hline Moisture & 7.8 & 7.8 & 7.7 & 7.8 \\
\hline Crude protein & 40.4 & 40.6 & 40.5 & 40.1 \\
\hline Crude lipid & 4.3 & 6.4 & 8.2 & 10.2 \\
\hline Ash & 8.1 & 8.2 & 8.1 & 8.0 \\
\hline Crude fiber & 2.62 & 2.58 & 2.53 & 2.48 \\
\hline $\mathrm{NFE}^{3}$ & 36.7 & 34.42 & 32.97 & 31.42 \\
\hline ME Kcal/100g ${ }^{4}$ & 344.92 & 354.98 & 364.14 & 373.23 \\
\hline $\mathrm{P} / \mathrm{E}$ ratio $^{5}$ & 117.12 & 114.37 & 111.22 & 107.44 \\
\hline
\end{tabular}

land 2 (NRC, 1983).

3. Nitrogen free extract $(N F E)=100-(\%$ Moisture $+\%$ protein $+\%$ fat $+\%$ Crude fiber $+\%$ ash $)$

4. Calculated according to values $4.5 \mathrm{Kcal} / \mathrm{g}$ protein, $8.15 \mathrm{Kcal} / \mathrm{g} \mathrm{fat}, 3.49 \mathrm{Kcal} / \mathrm{g}$ carbohydrate .(NRC. 1983).

5. P/E = Protein to energy ratio in $m g$ protein/ Kcal ME energy.

In contrast, some species such as beluga can utilize lipid levels up to $24 \%$, this may be due to different fish species or experimental conditions. The growth reduction at high lipid levels could be due to the reduced ability to digest and absorb high lipid, reduce in feed intake and/or fatty acid imbalance in feed (NRC ,1983). Feed intake (FI) increased from $7.92 \mathrm{~g}$ in fish group fed $4 \%$ crude lipid to a peak of $132.59 \mathrm{~g}$ in fish group fed $8 \%$ crude lipid, while fish fed $10 \%$ lipid showed a reduction in feed intake. It appears that fish like most of the terrestrials could adjust feed intake to satisfy energy requirements (Kaushik and Medale, 1994). When fish fed diet containing too high energy, decreased feed intake and growth depression was also reported by (El-Sayed and Garling ,1988) and (Ellis and Reigh ,1991). Improved feed conversion ratio and protein efficiency ratio with increasing dietary lipid level in Nile Tilapia larvae in the present study are in agreement with other studies (Pei et al., 2004; Einen and Roem, 1997and Weatherup et al., 1997). It has been reported that protein utilization can also be improved by increasing dietary energy level in many fishes (Cho and Kaushik, 1990; Beamish and Medland, 1986).For Nile tilapia larvae in this study, when dietary lipid level increased from 0 to $8 \%$, PER increased suggesting that increased dietary lipid level could spare dietary protein (Pei et al., 2004; Arzel et al., 1994; Chou and Shiau, 1996).

The FCR were improved significantly $(\mathrm{P}<0.05)$ for Nile tilapia larvae which fed diet containing $8 \%$ crude lipid than the rest of experimental groups. It appeared that fish could adjust feed intake to satisfy energy requirements (Kaushik and Medale, 1994). Feed consumption was negatively related to dietary energy content (Marais and Kissil, 1979; Ellis and Reigh, 1991).

When fish fed diet containing too high energy, feed intake decreased and growth depression was also reported by (El-Sayed and Garling , 1988 and Ellis and Reigh, 1991). Improved feed conversion efficiency and protein efficiency ratio with increasing dietary lipid level are in agreement with other studies (Einen and Roem ,1997; Weatherup et al., 1997; Nematipour et al., 1992). In contrast,( Peres and Oliva-Teles ,1999) did not observe protein sparing effect of lipid when they fed European sea bass juvenile's diets. This may be due different fish species or environmental condition. 
The mortality was $10 \%$ for group of fish fed $8 \%$ crude lipid, while the highest mortality rate was $30 \%$ for group of fish fed $4 \%$ crude lipid (Table 2). Considering that no clinical signs were noticed, it is plausible to infer that mortality was because of stress (Castro and Caballero, 2004).

Table (2): Growth performance for Nile tilapia fish, fed on different lipid level.

\begin{tabular}{|c|c|c|c|c|}
\hline \multirow{2}{*}{ Item } & \multicolumn{4}{|c|}{ lipid level } \\
\hline & $4 \%$ & $6 \%$ & $8 \%$ & $10 \%$ \\
\hline Initial weight (g) & $0.4 \pm 0.01$ & $0.4 \pm 0.01$ & $0.4 \pm 0.01$ & $0.4 \pm 0.01$ \\
\hline Final weight (g) & $3.7 \pm 0.32^{\mathrm{d}}$ & $4.3 \pm 0.35^{\mathrm{c}}$ & $6.8 \pm 0.36^{\mathrm{a}}$ & $5.7 \pm 034^{\mathrm{b}}$ \\
\hline Body weight gain ${ }^{1}$ & $3.3 \pm 0.40^{\mathrm{d}}$ & $3.9 \pm 0.35^{\mathrm{c}}$ & $6.4 \pm 0.36^{\mathrm{a}}$ & $5.3 \pm 0.32^{\mathrm{b}}$ \\
\hline Specific growth rate ${ }^{2}$ & $3.53 \pm 0.02^{\mathrm{d}}$ & $3.77 \pm 0.02^{c}$ & $4.5 \pm 0.02^{\mathrm{a}}$ & $4.22 \pm 0.02^{\mathrm{b}}$ \\
\hline Feed Intake (g) & $7.92 \pm 0.14^{\mathrm{d}}$ & $8.60 \pm 0.12^{\mathrm{c}}$ & $12.24 \pm 0.2^{\mathrm{a}}$ & $12.19 \pm 0.02^{\mathrm{b}}$ \\
\hline Feed conversion ratio $(\mathrm{FCR})^{3}$ & $2.40 \pm 0.3^{\mathrm{a}}$ & $2.21 \pm 0.3^{\mathrm{b}}$ & $1.91 \pm 0.3^{\mathrm{c}}$ & $2.30 \pm 0.2^{\mathrm{a}}$ \\
\hline Protein efficiency ratio (PER) ${ }^{4}$ & $1.19 \pm 0.1^{\mathrm{d}}$ & $1.30 \pm 0.1^{\mathrm{b}}$ & $1.49 \pm 0.1^{\mathrm{a}}$ & $1.24 \pm 0.1^{\mathrm{c}}$ \\
\hline Feed efficiency $(\mathrm{FER})^{5}$ & $0.42 \pm 0.01^{\mathrm{c}}$ & $0.45 \pm 0.01^{\mathrm{b}}$ & $0.52 \pm 0.01^{\mathrm{a}}$ & $0.43 \pm 0.01^{\mathrm{c}}$ \\
\hline Mortalities $(\%)^{6}$ & $30 \pm 2.00^{\mathrm{a}}$ & $20 \pm 2.00^{\mathrm{b}}$ & $10 \pm 2.00^{\mathrm{d}}$ & $15 \pm 2.00^{c}$ \\
\hline
\end{tabular}

Means having the same letter in the same row are not significantly different at $(P<0.05)$.

Values are means \pm SEM.

1 Weight gain $(W G)=($ final weight - initial weight $)$

2 Specific growth rate $(S G R)=($ ln final weight - In initial weight $) / /$ time days $\times 100$

3. $F C R=$ Feed intake $(g) /$ weight gain $(g)$

4. Protein efficiency $(P E)=($ final weight - initial weight $) / /($ protein intake $)$.

5. Feed efficiency $($ FER $)=($ Fish weight gain $) /($ feed intake $)$.

6. Mortality $(\%)=$ Number of fish survived at the end of the experiment - Number of fish stocked at the start of the experiment $X 100$

The effect of dietary lipid levels on body composition is presented in (Table 3). Dietary lipid level had a significantly $(\mathrm{P}<0.05)$ affected body lipid content. In the present study, the lipid contents of fish were positively correlated with dietary lipid level. (Tabachek,1986) stated that when dietary lipid was too high, the excess lipid was deposited within body tissues. (Williams and Robinson ,1988) reported that body lipid was increased with increased dietary lipid. Siddiqui et al., (1988) stated that there was an inverse relationship between water content and lipid content of Oreochromis niloticus larvae. The same authors noticed that the body protein content increased with increasing the protein levels in the diet.

Table (3): Whole body composition (wet weight basis), of Nile tilapia larvae fed the experimental diets.

\begin{tabular}{|l|c|c|c|c|c|}
\hline \multirow{2}{*}{ Item } & \multirow{2}{*}{ Initial } & \multicolumn{4}{|c|}{ Lipid level (\%) } \\
\cline { 3 - 6 } & & 4 & 6 & 8 & 10 \\
\hline Moisture (\%) & 72.9 & $73.3 \pm 0.2^{\mathrm{a}}$ & $73.3 \pm 0.3^{\mathrm{a}}$ & $73.1 \pm 01^{\mathrm{a}}$ & $73.5 \pm 0.2^{\mathrm{a}}$ \\
\hline Protein (\%) & 16.5 & $16.6 \pm 1.2^{\mathrm{a}}$ & $16.5 \pm 0.60^{\mathrm{a}}$ & $16.3 \pm 0.40^{\mathrm{a}}$ & $16.1 \pm 0.10^{\mathrm{a}}$ \\
\hline Total fat (\%) & 5.7 & $5.5 \pm 0.40^{\mathrm{d}}$ & $5.4 \pm 1.20^{\mathrm{c}}$ & $6.4 \pm 0.60^{\mathrm{a}}$ & $6.1 \pm 0.30^{\mathrm{b}}$ \\
\hline Ash (\%) & 4.9 & $4.6 \pm 0.10^{\mathrm{a}}$ & $4.8 \pm 0.40^{\mathrm{a}}$ & $4.2 \pm 0.20^{\mathrm{a}}$ & $4.3 \pm 0.40^{\mathrm{a}}$ \\
\hline
\end{tabular}

1 Mean plus SEM

In each row, values with the different letters are significantly different $(P<0.05)$.

\section{CONCLUSION}

Under the experimental conditions, the optimal dietary lipid level is $8 \%$ for Nile tilapia larvae. 


\section{REFERENCES}

Ahmadi .F. H.; B.Falahatkar; L. H. Ershad (2011). The influence of different lipid sources and levels on growth, body composition and hematology of Husohuso. J. Anim. Physiol. Anim. N. 95 (5), 632.

AOAC (2004). Official Methods of Analysis of the Association of Official Analytical Chemists. 14th Edn., AOAC, Arlington, VA.

Arzel, J.; L. F.Martinez and R.Métailler (1994). Effect of dietary lipid on growth performance and body composition of brown trout (Salmotrutta) reared in seawater. Aquaculture, 123, 361-375.

Beamish, F.W.H. and T.E. Medland (1986). Protein sparing effects in large rainbow trout, Salmo gairdneri. Aquaculture, 55, 35-42.

Bonvini, E.; L. Parma; L. Mandrioli; R. Sirri; C .Brachelente; F .Mongile; P.Gatta and A .Bonaldo (2015). Feeding common sole (Soleasolea) juveniles with increasing dietary lipid levels affects growth, feed utilization and gut health. Aquaculture 449, 87-93.

Bromley, P.J. (1980). Effects of dietary protein, lipid and energy content on the growth of turbot (Scophthalamus maximua L.) Aquaculture, 19, 359-369.

Castro, J.J. and C.Caballero (2004). Effect of the light intensity upon the agonistic behaviour of Juvenile of white-seabream (Diplodussar guscadenati) . Aggressive Behaviour, 30: 313-318.

Cho, C.Y. and S. J. Kaushik (1990). Nutritional energetics in fish: energy and protein utilization in rainbow trout (Salmo gairdneri). World Rev. Nutr. Diet, 61: 132-172.

Chou, B.S. and S.Y. Shiau (1996). Optimal dietary lipid level for growth of juvenile hybrid tilapia, Oreochromis niloticus x Oreochromis aureus. Aquaculture, 143: 185-195.

Duncan, D.B. (1955). Multiple range and multiple F-Test. Biometrics, 11: 1-42.

Einen, O. and A. J.Roem (1997). Dietary protein/energy ratios for Atlantic salmon in relation to fish size: Growth, feed utilization and slaughter quality. Aquaculture.Nutrtion., 3: 115-126.

Ellis, S.C. and R. C. Reigh (1991). Effects of dietary lipid and carbohydrate levels on growth and body composition of juvenile red drum Sciaenopsocellstus. Aquaculture, 97: 383-394.

El-Sayed, A.M. and J.R. Garling (1988). Carbohydrate-to-lipid ratio in diets for Tilapia zillii fingerlings. Aquaculture, 73: 157-163.

FAO (2009). Information and knowledge sharing. Food and Agriculture Organization of the United Nations Technical Guidelines for Responsible Fisheries No. 12, Rome.

FAO (2012). Food and Agriculture Organization of the United Nations. Accessed July 20, 2012.

FAO (2014). Management of inland waters for fish: a cross-sectoral and multi-disciplinary approach. In The state of world fisheries and aquaculture 2014.Food and Agriculture Organization of the United Nations, Rome. pp. 116-120.

Garling, D.J. and R.P. Wilson (1977). Effects of dietary carbohydrate-to-lipid ratio on growth and body composition of fingerling channel catfish. Prog. Fish-Cult., 39: 43-47.

Jauncey, K. (2000). Nutritional requirements. In M.C.M. Beveridge and B.J. McAndrew eds. Tilapias: Biology and Exploitation, pp. 327-375. Lancaster, United Kingdom, Kluwer Academic Publishers, 508 pp.

Kaushik, S.J. and F. Medale (1994). Energy requirement, utilization and dietary supply to salmonids. Aquaculture, 124: 81-97.

Lee, D.J. and G.B. Putnam (1973). The response of rainbow trout to varying protein/energy ratios in a test diet. J. Nutr., 103, 916-922

Liao, K.; J.Yan; K. S.Mai and Q. H. Ai (2016). Dietary lipid concentration affects liver mitochondrial DNA copy number, gene expression and DNA methylation in large yellow croaker (Larimichthys crocea). Comparative Biochemistry and Physiology B, 193, 25-32.

Marais J.F.K. and G.W. Kissil (1979). The infuence of energy level on the feed intake, growth, feed conversion and body composition of Spaurus aurata. Aquaculture 17, 203-219. 
Nematipour, G.R.; M.L. Brown and D.M. Gatlin (1992). Effects of dietary energy:protein ratio on growth characteristics and body composition of hybrid striped bass Morone chrysops X M. saxatilis. Aquaculture 107, 359-368.

NRC (1983). Nutrient Requirement of Warmwater Fishes and Shell-fishes.National Academy of Science, Washington, DC.

Pei, Z.; S.Xie ; W.Lei and X. Y. Zhu \& Yang (2004). Comparative study on the effect of dietary lipid level on growth and feed utilisation for gibel carp (Carassiusauratus gibelio) and Chinese longsnout catfish (Leiocassislongirostris Gunther). Aquaculture Nutrition., 10: 209-216.

Peng, S. M.; L. Q.Chen; J. G.Qin; J. L.Hou; N. Yu; Z. Q.Long and X. J. Sun (2015). Effects of replacement of dietary fish oil by soybean oil on growth performance and liver biochemical composition in juvenile black seabream, (Acanthopa grusschlegeli). Aquaculture, 276, 154-161.

Peres, H. and A.Oliva-Teles (1999). Effect of dietary lipid level on growth performance and feed utilization by European sea bass juveniles (Dicentrarchus labrax). Aquaculture, 179: 325-334.

Rahimnejad, S.; I. C.Bang; J. Y. Park; A. Sade; J.Choi and S. M. Lee (2015). Effects of dietary protein and lipidlevels on growth performance, feed utilization and body composition of juvenile hybrid grouper,( Epinephelusfusco guttatus)×(E. lanceolatus). Aquaculture, 446, 283-289.

Regost, C.; J. Arzel; M. Cardinal; J.Robin; M. Laroche and S.J. Kaushik (2001). Dietary lipid level, hepatic lipogenesis and flesh quality in turbot (Psetta maxima). Aquaculture, 193,

SAS (1999). SAS Statistical Software, version 8. SAS Institute, Cary, NC.

Siddiqui, A. Q.; M.S. Howlader and A.A. Adam (1988). Effects of dietary protein levels on growth, feed conversion and protein utilization in fry and young Nile tilapia (Oreochromis niloticus).

Aquaculture. 70:63-73.

Syed, R. S. ( 2017). Effect of varying levels of lipid on growth performance, survival and body composition of Milkfish (Chanos chanos). International Journal of Fisheries and Aquatic Studies 2017; 5(4): 30-34

Tabachek, J.L. (1986). Influence of dietary protein and lipid levels on growth, body composition and utilization efficiencies of Arctic charr,( Salvelinus alpinus )L .J.Fish .Biol , 29:139-151.

Watanabe, T. (1982). Lipid nutrition in fish. Comp. Biochem. Physiol. Part B: 73: 3-15.

Weatherup, R.N.; K.J.McCracken; R.Foy; D.Rice; J.McKendry; R.J. Mairs and R. Hoey (1997). The effects of dietary fat content on performance and body composition of farmed rainbow trout (Oncorhynchus mykiss). Aquaculture, 151: 173-184.

Williams C.D.and E.H. Robinson (1988). Response red drum to various dietary levels of menhaden oil. Aquaculture, 70: 107-120. 


\title{
الاحتياجات الغذائية من الدهون ليرقات سمك البلطى النيلى
}

\author{
عبد الحميد عيد1 ، رجاء عبد اللهّ2 ، السيد بغدادى1 ، امال الفقى و اسماء سمير عبد النبى3 \\ اقسم الانتاج الحيوانى والثروة السمكيةـ كلية الزراعة جامعة قناة السويس- الاسماعيليةـ مصر.

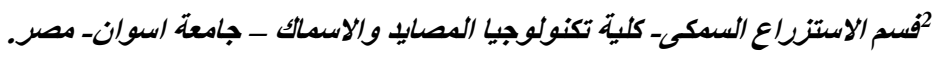 \\ 3قسم تغذية الاسماكـ المعدل المركزى لبحوث الثروة السمكيةـ العباسة ابو حماد شرقيهـ مصر.
}

اجريت هذه الدراسة لتقدير الإحتياجات الغذائية من الدهون ليرقات سمك البلطى النيلى حيث تم تغذية 4 مجمو عات من الأسماك على

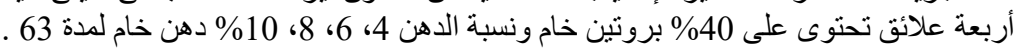

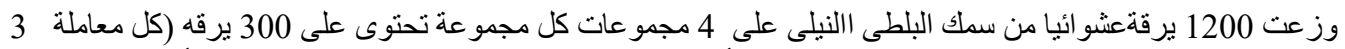

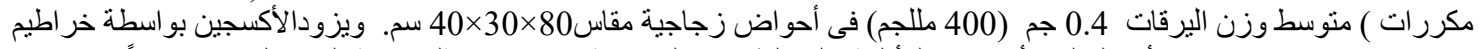

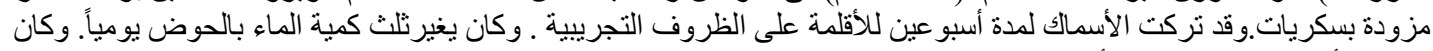
مصدر الأسماك مركزبحوث الأسماك جامعة قناةثالسويس.

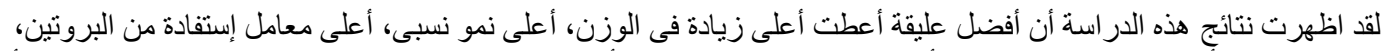

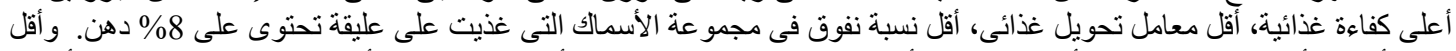

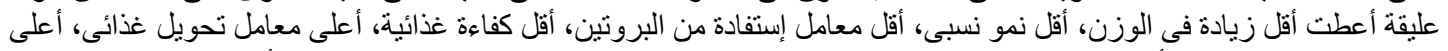

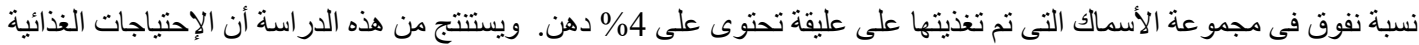

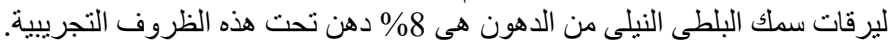

